\title{
Pola Asuh Positive Deviance dan Kejadian Stunting Balita di Kota Palembang
}

\author{
Febriani Dwi Bella ${ }^{1}$, Nur Alam Fajar ${ }^{2}$, Misnaniarti $^{3}$ \\ Fakultas Kesehatan Masyarakat Universitas Sriwijaya ${ }^{1,2,3}$ \\ mimikaiarsha@gmail.com
}

Diajukan 11 Mei 2019 Diperbaiki 11 Mei 2019 Diterima 20 November 2019

\section{ABSTRAK}

Latar Belakang: Stunting menjadi permasalahan utama gizi yang harus diselesaikan mengingat ini adalah ancaman bagi masa depan anak-anak Indonesia. Stunting dapat terjadi pada anak manapun yang tidak secara mutlak dipengaruhi oleh kemampuan ekonomi keluarga. Pada keluarga miskin masih dapat dijumpai anak dengan status gizi baik yang ditandai dengan tinggi badan yang normal. Dengan keadaan tersebut pola asuh keluarga positive deviance berperan besar terhadap status gizi anak. Pola asuh sebagai inti pendekatan positive deviance yaitu kebiasaan pemberian makan, kebiasaan pengasuhan, kebiasaan kebersihan dan kebiasaan mendapatkan pelayanan kesehatan.

Tujuan: Penelitian ini bertujuan untuk melihat gambaran pola asuh positive deviance dan kejadian stunting balita dari keluarga miskin di Kota Palembang.

Metode: Penelitian ini merupakan penelitian observasional dengan menggunakan pendekatan kualitatif dengan desain studi cross sectional.
Penelitian ini dilakukan pada ibu balita dari keluarga miskin di Kota Palembang, dengan informan sebanyak 5 (lima) orang ibu dari balita stunting dan 5 (lima) orang ibu dari balita normal (tidak stunting).

Hasil: Balita dengan tinggi badan normal (tidak stunting) dari keluarga miskin mendapatkan pola asuh positive deviance yaitu kebiasaan pemberian makan, kebiasaan pengasuhan, kebiasaan kebersihan dan kebiasaan mendapatkan pelayanan kesehatan yang baik. Sedangkan balita stunting dari keluarga miskin mendapatkan pola asuh yang tidak baik.

Kesimpulan: Ibu dari balita dengan tinggi badan normal memiliki pola asuh positive deviance berupa kebiasaan pemberian makan, kebiasaan pengasuhan, kebiasaan kebersihan dan kebiasaan mendapatkan pelayanan kesehatan yang baik terhadap balitanya dibandingkan dengan ibu dari balita stunting dengan latar belakang perekonomian yang sama.

Kata Kunci: stunting; pola asuh; positive deviance; balita

ABSTRACT
Background: Stunting is a major nutritional problem
that must be resolved considering this is a threat to the
future of Indonesian children. Stunting can occur in any
child who is not absolutely affected by the family's
economic abilities. In poor families can still found with
good nutritional status which is characterized by normal
height. With these condition positive deviance parenting
plays a major role in children's nutritional status.
Parenting is the core of the positive deviance approach,
namely feeding habits, nurturing habits, hygiene habits
dangetting health service habits.
Objective: This study aims to look at positive deviance
parenting and the incidence of stunting of toddlers from
poorfamilies in the city of Palembang.
Methods: This study was an observational study using a qualitative approach with a cross sectional study design. This research was conducted on mothers of toddler from poor families in the city of Palembang, with infromants as many as 5 (five) mothers from stunting toddlers and 5 (five) mothers from normal toddlers (not stunting).

Results: Toddlers with normal height (not stunting) from poor families get positive deviance parenting, in good feeding habits, good nurturing habits, good hygiene habits and good getting health services habits. Whereas stunting toddlers from poor families get poor parenting.

Conclusion: Mothers of toddlers with normal height have positive deviance parenting in the form of feeding habits, nurturing habits, hygiene habits and getting health service habits for their children better than mothers of stunting toddlers in the same economic background. 


\section{PENDAHULUAN}

Pembangunan nasional mempunyai tujuan dalam peningkatan mutu sumber daya manusia yang implementasinya dilaksanakan secara berkelanjutan, dimulai dari pemenuhan kebutuhan dasar manusia. Dalam menghasilkan sumber daya manusia yang berkualitas harus dirintis sejak dini dari kehamilan sampai pada tahap tumbuh kembang terutama pada periode emas kehidupan anak (Tanuwijaya, 2003). Fase terpenting dalam pertumbuhan dan perkembangan anak ketika masa bayi dan balita, karena pada masa tersebut adalah masa untuk membangun dasar tumbuh kembang anak dalam menentukan masa depan anak baik secara fisik, mental maupun perilaku (Sunartyo, 2007) dan di masa ini anak memerlukan perhatian lebih terutama kecukupan gizinya (Kurniasih, 2010). Kecukupan gizi balita berdampak pada keseimbangan fisik dan mentalnya, sedangkan ketidakcukupan gizi akan berdampak pada menurunnya produksi antibodi dalam tubuh sehingga penyakit mungkin masuk ke dalam tubuh (Rambitan, Purba dan Kapantow, 2014).

Adanya penyebaran permasalahan gizi terutama stunting yang tidak merata menyebabkan adanya kawasan dengan kejadian stunting yang rendah di wilayah dengan tingkat kemiskinan yang tinggi. Data dari Dinas Sosial Kota Palembang menyebutkan bahwa jumlah keluarga Penerima Program Keluarga Harapan (PKH) sebagai indikator tingkat kemiskinan di Kota Palembang sebanyak 53.678 Keluarga Penerima Manfaat (KPM). Program Keluarga Harapan adalah program pemberian bantuan sosial bersyarat kepada Keluarga Penerima Manfaat sebagai upaya percepatan penaggulangan kemiskinan yang bertujuan untuk mengurangi beban pengeluaran serta memberikan nutrisi yang lebih seimbang secara tepat sasaran dan tepat waktu (Kemensos RI, 2018). Dari data tersebut menunjukkan bahwa penyebaran keluarga miskin di Kota Palembang tidak sejalan dengan jumlah kejadian stunting. Hal tersebut menggambarkan bahwa di dalam keluarga miskin di Kota Palembang, persentase jumlah balita dengan status gizi baik cukup tinggi ditunjukkan dengan angka kejadian stunting yang rendah. Data Riskesdas 2013 menyebutkan bahwa prevalensi pendek dan sangat pendek di Kota Palembang sebesar $27,4 \%$. Permasalahan stunting balita di Kota Palembang menduduki posisi teratas dibandingkan dengan permasalahan gizi KEP lain yang dialami oleh balita (Dinas Kesehatan Kota Palembang, 2017).

Permasalahan gizi dapat dicegah dengan mengenali akar masalah yang terjadi di masyarakat sehingga penanganan masalah gizi dapat dilakukan secara mendasar pada sumber masalah. Salah satu pendekatan yang dapat digunakan dalam upaya preventif dan promotif dalam masyarakat yaitu pendekatan positive deviance. Pendekatan ini merupakan suati model untuk merubah perilaku masyarakat dalam meningkatkan status gizi melalui perilaku positif. Penanganan status gizi pada keluarga miskin sangat tepat dilakukan dengan pendekatan positive deviance ini. Positive deviance adalah pendekatan untuk memecahkan permasalahan gizi dengan berdasarkan keluarga dan masyarakat dengan mengenali kebiasaan ibu dari anak dengan gizi baik dan berasal dari keluarga miskin dan mampu menyebarkan kebiasaan positif pada ibu dari anak dengan gizi yang kurang/buruk. Kebiasaan positif dalam keluarga sebagai dasar dari pendekatan positive deviance dibedakan dalam 4 (empat) pola kebiasaan yaitu pemberian makan, pengasuhan, kebersihan dan mendapatkan pelayanan kesehatan (CORE, 2004).

Berdasarkan latar belakang masalah tersebut, perlu dilakukan penelitian yang akan menggambarkan pola asuh positive deviance dan kejadian stunting balita dari keluarga miskin di Kota Palembang.

\section{METODE}

Penelitian ini merupakan penelitian 
observasional dengan menggunakan pendekatan kualitatif dengan desain studi cross sectional. Penelitian ini dilakukan pada ibu balita dari keluarga miskin di Kota Palembang, dengan informan sebanyak 5 (lima) orang ibu dari balita stunting dan 5 (lima) orang ibu dari balita normal (tidak stunting). Kriteria keluarga miskin yang digunakan dalam penelitian ini adalah keluarga penerima Program Keluarga Harapan (PKH) dari pemerintah berdasarkan Data Dinas Sosial Kota Palembang Tahun 2018. Teknik pengambilan sampel informan penelitian dilakukan dengan teknik purposive sampling yaitu dipilih sampel yang sesuai dengan tujuan penelitian.

Jenis data primer yang digunakan adalah data yang diambil dari informan mengenai kebiasaan pemberian makan, kebiasaan pengasuhan, kebiasaan kebersihan dan kebiasaan mendapatkan pelayanan kesehatan yang didapat dari wawancara dan observasi serta kejadian stunting balita yang didapat dari hasil pengukuran tinggi badan balita. Data sekunder yang dipakai meliputi jumlah populasi dan gambaran tempat penelitian yang diperoleh dari Dinas Kesehatan Kota Palembang dan Dinas Sosial Kota Palembang.

Instrumen yang digunakan dalam penelitian ini adalah panduan wawancara mendalam dan observasi tentang kebiasaan pemberian makan, kebiasaan pengasuhan, kebiasaan kebersihan dan kebiasaan mendapatkan pelayanan kesehatan, serta alat ukur tinggi badan balita untuk mengetahui kejadian stunting balita. Wawancara mendalam dilakukan dengan mengumpulkan data yang diperoleh dari informan, direkam menggunakan alat perekam, selanjutnya diketik menjadi transkrip untuk setiap informan yang dikelompokkan sesuai dengan variabel yang diteliti. Sedangkan observasi dilakukan dengan pengamatan langsung bertujuan untuk memeriksa kesesuaian dan kelengkapan antara daftar pertanyaan dengan data yang diobservasi sehingga dapat diambil kesimpulan.

\section{HASIL DAN PEMBAHASAN \\ 1. Kejadian Stunting Balita}

Stunting didapatkan dari hasil pengukuran dengan Z-score TB/U kurang dari 2 SD berdasarkan rujukan WHO-NHCS dengan berpedoman pada Surat Keputusan $\mathrm{M}$ e $\mathrm{nt}$ e $\mathrm{r} \mathrm{K}$ e s e h a $\mathrm{t}$ a $\mathrm{n}$ o m o r 1995/Menkes/SK/XII/2010 tentang Standar Antropometri Penilaian Status Gizi Anak. Pada penelitian ini diketahui dari hasil pengukuran pada 100 balita dari keluarga miskin di Kota Palembang, sebagian besar balita memiliki tinggi badan normal yaitu sebanyak 71 orang dan balita stunting sebanyak 29 orang.

\section{Kebiasaan Pemberian Makan}

Hasil wawancara dengan informan ibu balita dengan tinggi badan normal (tidak stunting) tentang kebiasaan pemberian makan yang dilakukan oleh ibu balita adalah sebagai berikut:

"Makannyo banyak, lahap, sehari tigo kali bahkan lebih. Dimakannyo galo, nasi, sayur bahkan sambel laju galo. Kalo dio bosen dio minta, hobinya ayam samo ikan,sayurnyo laju galo, buah kadangkadang ado, cemilan pasti ado pempek, bolu, pepes cak tadi, maknyo rajin masak. Jajan dak terlalu banyak karno dimasak"i makanan terus di rumah. Makannyo memang banyak dari dulu kecuali pas sakit banyakminum susu bae." (Ny.Mr)

Selanjutnya pada ibu balita stunting terlihat kebiasaan pemberian makan sebagai berikut hasil wawancaranya:

"Waktu lahir belum keluar ASI, Netek bae sampe tigo bulan, abis itu lah pacak duduk kukasih susu botol lagi. Pas enam bulan makan kadang dimasakke nasi bae dipirik. Kalo sekarang makannyo nasi gemuk, jajan, susu, roti goreng. Aku dakpernah masak masak beli aku tuh, repot masak tuh nak ngambek cepetnyo bae. Dio galak jajan, ciki, permen kularang tapi maling-maling, kalo dak dienjuk nangis tepakso keluar duit. Kapan banyak makan nak mising jadi dikit makannyo. Dio makan dewek dakgalak disuapi." (Ny. St)

Berdasarkan wawancara yang dilakukan diatas, diperoleh informasi mengenai bentuk 
kebiasaan pemberian makan yang baik pada balita berupa pendampingan makan balita, pengolahan makanan oleh ibu sendiri dan pemberian makan secara rutin. Dari informasi yang digali, kebiasaan-kebiasaan ini dilakukan oleh ibu balita dengan tinggi badan normal dan tidak diterapkan oleh ibu yang memiliki balita stunting. Dari wawancara menyebutkan, ibu balita stunting cenderung membiarkan balita makan sendiri, frekuensi pemberian makan mengikuti kemauan anak dan makanan didapat dari membeli di lingkungan sekitar rumah.

Pendampingan dalam pemberian makan sangat dibutuhkan oleh balita dan merupakan hal yang sangat penting dalam proses pertumbuhannya. Hal ini dilakukan dengan memberikan suasana yang nyaman bagi balita, pendampingan berupa perhatian saat memberikan makan sehingga terjadi interaksi positif antara ibu dan balita yang bertujuan agar anak diharapkan mampu menghabiskan porsi makanan yang diberikan (Yudianti, 2016). Ibu yang memberikan perhatian dan dukungan lebih dalam hal pemberian makan anak akan berpengaruh positif kepada keadaan status gizi anak (Rahmayana, 2014). Anak memerlukan bantuan saat makan dikarenakan bila anak makan sendiri kemungkinan makan yang sedikit dan gangguan saat makan. Bila anak menolak untuk dibantu, pendampingan makan tetap perlu dilakukan untuk memastikan kuantitas makan anak (Kahfi, 2015).

Kebiasaan pemberian makan yang baik juga tampak pada cara pengolahan makanan yang disajikan untuk balita. Pemberian makanan pada balita baik makanan utama maupun selingan yang dimasak sendiri oleh ibu berpengaruh positif dalam peningkatan status gizi anak. Hal ini disebabkan ibu mengetahui dengan pasti kandungan dan bahan makanan yang akan diberikan pada balitanya. Pada penelitian lain yang melihat perilaku ibu dalam pemberian makanan dari jajanan yang tersedia di lingkungan sekitar, ditemukan bahwa asuhan pemberian makan yang dilakukan oleh ibunya sendiri dapat mencegah adanya gangguan terhadap kesehatan anak. Adanya gangguan kesehatan tersebut dapat menyebabkan penurunan kekebalan tubuh anak disebabkan kurangnya asupan gizi seimbang (Nasution, 2011).

Kebiasaan pemberian makan yang penting lainnya yaitu pemberian makan yang rutin pada anak. Balita yang secara rutin diberikan makanan utama dan cemilan setiap harinya berpotensi untuk memiliki status gizi yang baik. Beberapa penelitian yang menyebutkan pola asuh pemberian makan yang dilakukan ibu pada balita stunting sebagian besar kurang tepat dimana ibu tidak memperhatikan kebutuhan gizi balita. Ibu balita stunting memiliki kebiasaan menunda memberikan makan pada balita. Kondisi ini menyebabkan kurangnya asupan makan balita baik secara kualitas dan kuantitas sehingga menimbulkan kerawanan balita mengalami stunting (Widyaningsih, 2018).

\section{Kebiasaan Pengasuhan}

Hasil wawancara dengan informan dari balita normal tentang kebiasaan pengasuhan pada balitanya dapat dilihat sebagai berikut:

"Adek ni samo ibu ni lah. Palingan kalo kakak samo ayuknyo di rumah maen samo mereka, ibu biso nggaweke gawean rumah apo misal ado jaitan. Ayuknyo jugo kadang-kadang bantu gawean rumah jugo. Pokoknyo kalo samo adek ni diperhatike nian, karno jaraknyo kan lumayan jauh dari kakaknyo jadi disayang nian samo ayuk-ayuknyo, jadi rewang ibu jugo kalo katek uwong dirumah." (Ny.Pn)

Selanjutnya pada ibu balita stunting didapat informasi tentang kebiasaan pengasuhan yang dilakukan pada balitanya dengan didapatkan hasil wawancara sebagai berikut:

"Kalo ditinggal ado acara-acara samo neneknyo, dak katek omongan apo-apo lah biaso dititip makn nitip bae. Anak ini lemah jadi diawasin nian. Dak pernah diajak becerito paling bedoa sebelum tiduk. Dak pernah dimarahi paling diomongin bae, ditakuti bae kalo dio nak keluar rumah jadidakkeluar-keluar." (Ny. Na)

Berdasarkan hasil wawancara di atas 
menunjukkan bentuk kebiasaan pengasuhan yang baik dilakukan oleh ibu adalah pengasuhan dominan oleh ibu sendri sebagai pengasuh utama dan melibatkan seluruh anggota keluarga dalam memberikan rangsangan psikososial melalui bermain dan aktivitas fisik balita. Ibu yang memiliki balita stunting menyatakan bahwa balita tidak diperbolehkan bermain di luar rumah dan pengasuhan dilakukan ibu tanpa keterlibatan seluruh anggota keluarga lain.

Kebiasaan pengasuhan yang ditemukan dalam penelitian ini adalah pentingnya rangsangan/stimulasi dalam peningkatan status gizi balita. Stimulasi tumbuh kembang anak dapat dilakukan pula dengan memberikan permainan karena adanya pertimbangan bahwa dengan bermain anak akan belajar dari kehidupan. Bermain adalah salah satu aktivitas yang memberikan stimulasi dalam kemampuan kognitif dan afektif. Stimulasi adalah hal yang dibutuhkan dan bersifat penting dalam tumbuh kembang anak. Anak yang mendapat stimulasi terarah dan teratur akan lebih cepat berkembang dibandingkan dengan anak yang kurang/tidak mendapat stimulasi (Soetjiningsih, 1995). Menimbang hal tersebut, aktivitas bermain anak sangat penting dan aktivitas anak dengan teman sebaya akan mendukung pertumbuhan dan perkembangan anak. Stimulasi yang diberikan pada anak akan menyebabkan stimulasi hormon pertumbuhan, metabolisme energi menjadi normal dan imun respon menjadi lebih baik (Zeitlin et al., 1990). Pola asuh yang membatasi anak dalam bersosialisasi dan berinteraksi dengan teman sebaya dapat menghambat proses tumbuh kembang anak.

\section{Kebiasaan Kebersihan}

Hasil wawancara dengan informan ibu dari balita normal didapatkan informasi tentang kebiasaan kebersihan yang dilakukan pada balitanya sehari-hari dengan pernyataan berikut:

"Mandi samo ibu, kadang-kadang mandi samo-samo, pake sabun digosok-gosokin, rajin gosok gigi. Maen biarlah dalam rumah, daripada dio maen kotor apolagi ujan-ujan becek. Maen keluar pake sendal terus. Kalo nyapu dirumah ini empat kali sehari, nyampu halaman tiap hari karno ado daun." (Ny.Sm)

Selanjutnya pada ibu balita stunting didapat informasi tentang kebiasaan kebersihan yang dilakukan pada balitanya dengan hasil wawancara sebagai berikut:

"Dio dak kumandike, mandi dewekan, pake sabun dewek, gosok gigi dewek. Gawenyo besalin baju sampe belumbuk baju belum dicuci. Kalo amen kotor kumarahi, galak maen di got balek-balek kumarahi kau ye gantibaju sano. Kalo nyebok' in aku atau ayuknyo tu lah belum bersih dio kalo cebok dewek." (Ny. St)

Hasil penelitian menunjukkan bahwa bentuk kebiasaan kebersihan yang baik yang dilakukan informan antara lain menggosok gigi dengan rutin, membersihkan buang air, membersihkan ruangan dalam rumah dan sekeliling rumah. Secara umum kebiasaan kebersihan diri dan sanitasi yang dilakukan ibu telahs esuai dengan syarat kesehatan tubuh dengan mandi dua kali sehari, rambut, tangan, kaki dan pakaian harus bersih, menggosok gigi, menjaga kebersihan makanan dan menghindari sumber penularan penyakit seperti sampah.

Kebersihan diri merupakan faktor yang berhubungan dengan kejadian stunting. Kebiasaan mencuci tangan sebelum makan, sebelum menyiapkan makanan, setelah buang air besar dan setelah memegang hewan yang dilakukan ibu dengan anak status gizi normal jumlahnya lebih banyak dibandingkan ibu dari kelompok anak stunting (Aditianti, 2010). Peran dari kebersihan tubuh, makanan dan lingkungan dalam memelihara kesehatan akan mencegah penyakit infeksi pada anak (Turnip, 2008). Praktek kebersihan diri anak akan mempengaruhi pertumbuhan linier anak melalui peningkatan kerawanan terjangkitnya penyakit infeksi (Lestari, 2014).

Kebersihan lingkungan yang tidak baik seperti kebersihan ruangan rumah, sekeliling 
rumah, pengelolaan sampah sampai pada penyediaan air bersih yang tidak memadai berpotensi menimbulkan penyakit pada anak (Turnip, 2008). Pada penelitian Astari (2005) di Kabupaten Bogor menyebutkan ada hubungan yang signifikan antara praktek sanitasi lingkungan dengan morbiditas penyakit ISPA dan diare. Ibu yang memperhatikan kondisi kebersihan lingkungan baik di dalam rumah maupun lingkungan sekitar berdampak positif pada status gizi anak. Sebagian besar balita dengan tinggi badan normal memiliki kondisi lingkungan rumah yang lebih baik dibandingkan kondisi linkungan rumah balita stunting. Ini menunjukkan bahwa pentingnya ibu untuk memperhatikan kondisi lingkungan sehingga anak bebas mengeksplorasi diri di lingkungan yang bersih dan nyaman.

\section{Kebiasaan Mendapatkan Pelayanan Kesehatan}

Hasil wawancara dengan informan ibu balita normal tentang kebiasaan mendapatkan pelayanan kesehatan terhadap balitanya didapatkan sebagai berikut:

"Ibu nih ketua posyandu, jadi di rumah ni lah posyandu jadi adek pasti ditimbang tiap bulan, dijingok KMSnyo naek apo turun. Alhamdulillah naek terus selamo ini. Imunisasinyo lengkap, pernah lewat karno demam, terus pas sudah dak demam ibu dateng lagi ke puskesmas. Kalo demam biasonyo ibu siapke penurun panas, dikompres. Alhamdulillah sejauh ini belum pernah adek sakit parah. Kalo ado penyuluhan dari puskesmas atau PKK ibu sempetke data kalo misal dak ado tumburan acara." (Ny.Pn)

Selanjutnya pada ibu balita stunting terlihat kebiasaan mendapatkan pelayanan kesehatan dengan hasil wawancara sebagai berikut:

Imunisasinyo dak lengkap, cuman sekali dari balek lahiran itu ye, sudah. Ditimbang tiap bulan kalo aku perikso hamil bae kutimbang dio. Nyirenin dio nak sakit kadang cak lesu-lesu, nah budak ini nak demam, kudiemke dulu kalo cak ingus-ingusan belike dulu obat di apotik. Kalo pas sakit dak do dipakso makan, enjuksusu bae." (Ny. M)

Hasil wawancara diatas menunjukkan bentuk kebiasaan mendapatkan pelayanan kesehatan yang baik yang dilakukan ibu dari balita normal adalah pemberian imunisasi dasar yang lengkap dan sesuai umur, pemberian vitamin A secara rutin dan pemanfaatan pelayanan kesehatan yang tepat dari tenaga kesehatan yang profesional.

Imunisasi dasar sangat penting bagi balita untuk mengatasi gangguan kekebalan tubuh terhadap penyakit infeksi dikarenakan produksi antibodi yang menurun mengakibatkan mudahnya penyakit masuk ke dalam tubuh balita. Bila balita tidak memiliki imunitas terhadap penyakit maka balita akan lebih cepat kehilangan energi tubuh disebabkan penyakit infeksi yang menghambat reaksi imunologi. Ini berpengaruh pada produksi enzim pencernaan makanan sehingga makanan tidak dapat dicerna dengan baik yang menyebabkan penyerapan gizi akan terganggu dan memperburuk keadaan gizi anak. Dampak akhirnya yaitu gagalnya pertumbuhan optimal anak yang sesuai dengan pertambahan umur sehingga mempertinggi kejadian stunting (AlRahmad, 2013).

Pemanfaatan pelayanan kesehatan yang dilakukan oleh ibu untuk balitanya yaitu kunjungan rutin ke Posyandu dalam upaya mendapatkan informasi kesehatan balita yang dibagikan oleh tenaga kesehatan (Panjaitan, 2011). Ibu yang memantau pertumbuhan balita melalui Posyandu dengan kegiatan penimbangan akan lebih dini mendapatkan informasi kesehatan tentang tumbuh kembang balitanya (Yusnidaryani, 2009). Selain itu pemanfaatan pelayanan kesehatan juga ditandai dengan pencarian pengobatan saat anak sakit pada tenaga kesehatan profesional. Kesehatan anak hendaknya harus mendapat perhatian dari orang tua dengan segera membawa anaknya yang sakit ke tempat pelayanan kesehatan terdekat (Soetjiningsih, 1995). Sakit yang memakan waktu lama dan berulang akan berdampak pada turunnya nafsu makan anak dan akibatnya asupan gizi anak yang rendah. Perilaku ibu dalam menghadapi anak sakit dan pemantauan 
kesehatan terprogram adalah pola pengasuhan yang mempengaruhi tumbuh kembang anak secara optimal. Pencarian pengobatan pada pelayanan kesehatan yang tepat seperti Puskesmas, praktek dokter dan praktek bidan berhubungan dengan status gizi balita. Sebagian besar ibu dengan asuhan perawatan kesehatan yang baik mempunyai anak balita dengan status gizi normal (Nasution, 2011)

\section{PENUTUP}

Ibu dari balita dengan tinggi badan normal memiliki pola asuh positive deviance berupa kebiasaan pemberian makan, kebiasaan pengasuhan, kebiasaan kebersihan dan kebiasaan mendapatkan pelayanan kesehatan yang baik terhadap balitanya. Sedangkan ibu dari balita stunting memiliki kebiasaan pola asuh yang tidak baik meskipun dari latar belakang perekonomian yang sama.

Perlunya peningkatan pengetahuan ibu tentang pola asuh baik dari kebiasaan pemberian makan, kebiasaan pengasuhan, kebiasaan kebersihan dan kebiasaan mendapatkan pelayanan kesehatan melalui pencarian informasi secara mandiri sehingga diharapkan dapat meningkatkan sikap dan perilaku ibu dalam menjaga staus gizi balita.

\section{DAFTAR PUSTAKA}

Aditianti. (2010). Faktor Determinan Stunting pada Anak Usia 24-59 bulan di Indonesia. Tesis. Institut Pertanian Bogor.

Astari, L. D., Nasoetion, A. And Dwiriani, C. (2005). Hubungan Karakteristik Keluarga, Pola Pengasuhan dan Kejadian Stunting Anak Usia 6-12 bulan. Media Gizi dan Keluarga. 29(2): 40-46.

Core. (2004). Positive Deviance \& Hearth: Buku Panduan Pemulihan yang berkesinambungan bagi Anak Malnutrisi. Edisi Kedua. Diterjemahkan oleh PCI-Indonesia.

Dinas Kesehatan Kota Palembang. (2017). Laporan Hasil Operasi Timbang 2017. Palembang.

Kahfi, A. (2015). Gambaran Pola Asuh pada BAduta Stunting Usia 13-24 Bulan di
Wilayah Kerja Puskesmas Neglasari Kota Tangerang. Skripsi. Universitas Islam Negeri Syarif Hidayatullah Jakarta.

Kementerian Sosial RI. (2018). Bantuan Pangan

Non Tunai. Available from: https://www.kemsos.go.id/page/bantua n-pangan-non-tunai. Diakses tanggal 3 November 2018.

Kurniasih. (2010). Sehat dan Bugar Berkat Gizi Seimbang. Gramedia. Jakarta.

Lestari, W., Margawati, A. And Rahfiludin, M. Z. (2014). Faktor Risiko Stunting pada Anak Umur 6-24 bulan di KEcamatan Penanggalan Kota Subulussalam Provinsi Aceh. Jurnal Gizi Indonesia. 3(1) : 37-45.

Nasution, B. (2011). Pengaruh Pola Asuh Ibu Terhadap Status Gizi Balita Keluarga Miskin di Kecamatan Panyabungan Utara Kabupaten Mandailing Natal tahun 2011. Tesis. Universitas Sumatera Utara.

Panjaitan, R. (2011). Pola Asuh Ibu dan Status Gizi Anak Balita di Kecamatan Pollung Kabupaten Humbang Hasundutan Tahun 2011. Tesis. Universitas Sumatera Utara.

Rahmayana. (2014). Hubungan Pola Asuh Ibu dengan Kejadian Stunting Anak Usia 2459 bulan di Posyandu Asoka II Wilayah Pesisir Kelurahan B Arombong Kecamatan Tamalate Kota Makasar Tahun 2014. Al Sihah: Public Health Science Journal. 6(2) : 424-436.

Rambitan, W., Purba, R. B. And Kapantow, N. H. (2004). Hubungan Antara Riwayat Pemberian ASI Eksklusif Dengan Kejadian Stunting Pada Anak Batita di Wilayah Kerja Puskesmas Kawangkoan Kabupaten Minahasa. Tesis. Universitas Sam Ratulangi.

Soetjiningsih. (1995). Tumbuh Kembang Anak. Penerbit Buku Kedokteran EGC. Jakarta.

Sunartyo. (2007). Panduan Merawat Bayi dan Balita. Diva Press. Yogyakarta.

Tanuwijaya, S. (2003). Konsep Umum Tumbuh dan Kembang. Penerbit Buku Kedokteran 
EGC. Jakarta.

Turnip, F. (2008). Pengaruh Positive Deviance pada Ibu dari Keluarga Miskin Trehadap Status Gizi Anak Usia 12-24 Bulan di Kecamatan Sidikalang Kabupaten Dairi Tahun 2007. Tesis. Universitas Sumatera Utara.

Widyaningsih, N. N., Kusnandar, and Anantanyu, S. (2018). Keragaman Pangan, Pola Asuh Makan dan Kejadian Stunting pada Balita Usia 24-59 bulan. Jurnal Gizi Indonesia. 7(1): 22-29.

Yudianti and Saeni, R. H. (2016). Pola Asuh dengan Kejadian Stunting pada Balita di Kabupaten Polewali Mandar. Jurnal
Kesehatan Manarang. 2(1):21-25.

Yusnidaryani. (2008). Pengaruh Pola Asuh Terhadap Status Gizi Bayi PAda Keluarga Miskin dan Tidak Miskin di Kabupaten Aceh Utara. Tesis. Universitas Sumatera Utara.

Zeitlin, M., Ghaessemi, H., Mansour, M., Levine, R. A., Dillanneva, M., Carballo, M., Sockalingam, S. (1990). Positive Deviance in Child Nutrition : With Emphasis on Psychosocial and Behavioural Aspects and Implicatons for Development. 